\title{
Partial replacement of corn by forage cactus in the diets of lactating goats
}

\section{Substituição parcial do milho pela palma forrageira em dietas para cabras em lactação}

\author{
Julianne Santiago Silva Goveia'; Veronaldo Souza de Oliveira²; \\ Gladston Rafael de Arruda Santos'; Karla Dias Antunes Melo ${ }^{3 *}$, \\ Aline Guimarães de Oliveira ${ }^{1}$; Marcus Vinicius Andrade Melo ${ }^{4}$
}

\begin{abstract}
The objective of this trial was to evaluate the effect of the partial replacement of corn by forage cactus (Nopalea cochenillifera Salm Dyck) in the diets of lactating goats on the nutrient intake, milk production and composition and ingestive behavior. Five crossbreed Saanen x Pardo Alpina goats with body weights of $47 \pm 3.3 \mathrm{~kg}$ were used in the study. The design was $5 \times 5$ Latin square design, in which the treatments were as follows: $20,25,30,35$ and $40 \%$ of girl cactus included in the diet as a partial replacement of corn, with $0,18,36,54$ and $72 \%$ of the added the cactus comprising of gliricidia (Gliricidia sepium (Jacq) Walp) as roughage in all treatments. Treatment did not affect $(\mathrm{P}>0.05)$ the dry matter intake, crude protein, neutral detergent fiber, acid detergent fiber and total digestible nutrients with the increasing levels of cactus in the diet, presenting means of 1.64, 0.26, 0.82, 0.54 and 1.17 $\mathrm{kg} \mathrm{day}^{-1}$, respectively. In the same way, no influence was observed on the daily milk production and levels of fat, protein, lactose and total solids of milk, which averaged $1.18 \mathrm{~kg} \mathrm{day}^{-1} ; 3.74,3.34,5.06$ and $13.56 \%$, respectively. The inclusion of cactus also had no influence $(\mathrm{P}>0.05)$ on the ingestion behavior. The treatment with $35 \%$ cactus showed a lower impairment of food intake (31\%). The partial replacement of the corn by the girl cactus in the diets of dairy goats can be accomplished because it does not alter the intake, milk yield and composition and feeding behavior. The replacement of up to $54 \%$ corn by the cactus is recommended to reduce producer costs for food.
\end{abstract}

Key words: Goats. Intake. Milk yield. Semiarid.

\section{Resumo}

Objetivou-se avaliar a substituição parcial do milho (Zea mays L.) pela palma forrageira miúda (Nopalea cochenillifera- Salm Dyck) em dietas de cabras em lactação sobre o consumo de nutrientes, produção e composição do leite, comportamento ingestivo e o comprometimento da receita com alimentação. Foram utilizadas 5 cabras mestiças de Saanen x Pardo Alpina, com peso corporal de $47 \pm 3,3 \mathrm{~kg}$. O delineamento utilizado foi o quadrado latino $5 \times 5$, em que os tratamentos consistiram em níveis de 20 , $25,30,35$ e $40 \%$ de palma forrageira miúda incluídos na dieta em substituição ao milho que foram de 0 , $18,36,54$ e $72 \%$ tendo o feno de gliricídia (Gliricídia sepium (Jacq) Walp) como volumoso em todos os

\footnotetext{
${ }^{1}$ Mestres em Zootecnia, Universidade Federal de Sergipe, UFS, São Cristovão, Sergipe, Brasil. E-mail: julygoveia@gmail.com; veronaldo@ufs.br

2 Profs. Drs., Dept ${ }^{\circ}$ de Zootecnia, UFS, São Cristovão, Sergipe, Brasil. E-mail: veronaldo@ufs.br; gladstonrafael@yahoo.com.br

${ }^{3}$ Discente do Curso de Doutorado em Ciência Animal, Universidade Federal de Minas Gerais, UFMG, Pampulha, MG, Brasil. E-mail: kda_vet@hotmail.com

${ }^{4}$ Discente do Curso de Graduação em Zootecnia, UFS, São Cristovão, Sergipe, Brasil. E-mail: veronaldo@ufs.br

* Author for correspondence
} 
tratamentos. Os tratamentos não influenciaram $(\mathrm{P}>0,05)$ o consumo de matéria seca, proteína, fibra em detergente neutro, fibra em detergente ácido e nutrientes digestíveis totais apresentando médias iguais a 1,$64 ; 0,26 ; 0,82 ; 0,54$ e $1,17 \mathrm{~kg} \mathrm{dia}^{-1}$, respectivamente. Do mesmo modo, não houve influência dos níveis sobre a produção de leite e os teores de gordura, proteína, lactose e sólidos totais do leite apresentando médias iguais a $1,18 \mathrm{~kg} \mathrm{dia}^{-1} ; 3,74 ; 3,34 ; 5,06$ e $13,56 \%$, respectivamente. O comportamento ingestivo também não sofreu influência com a inclusão de palma nas dietas. O tratamento com $35 \%$ de palma demonstrou menor comprometimento da receita com alimentação (31\%). A substituição parcial do milho pela palma forrageira miúda em dietas para cabras leiteiras pode ser realizada, pois não altera o consumo, a produção de leite e sua composição e o comportamento ingestivo. Recomenda-se substituir em até $54 \%$ o milho pela palma por apresentar menor comprometimento da receita do produtor com a alimentação.

Palavras-chave: Caprinos. Consumo. Produção de leite. Semiárido.

\section{Introduction}

In the semiarid region of northeastern Brazil, the production of dairy goats is important for generating food and income on rural properties where savanna vegetation serves as a major forage source. However, during the shortages caused by the rainy seasons, a lack of food makes the farmers extremely dependent on commercial concentrated foods. Among the alternative food sources, spineless cactus (Opuntia ficus indica Mill) stands out as one cactus that is well adapted to the climatic characteristics of the region; it is rich in nonfibrous carbohydrates and provides high dry matter production per hectare (DE KOCK, 2001; DUSKOVÁ; MAROUNEK, 2001; WANDERLEY et al., 2002; MELO et al., 2003). Beltrão Filho (2008) evaluated the effects of replacing corn meal with spineless cactus $(0,25,50,75$ and $100 \%$ ) on nutrient intake, feeding behavior, blood parameters, milk production and feed costs for lactating goats and concluded that the cactus can replace corn bran and increase dry matter intake without affecting the milk production, thereby providing greater profitability for the producer, as well as reducing water consumption by the animals. Legumes are also considered an alternative food source and are an excellent source of fiber and protein for ruminants. Gliricidia (Gliricidia sepium (Jacq) Walp) a leguminous plant adapted to the soil and climatic conditions of the semiarid region, has foliage with crude protein contents ranging from 20 to $30 \%$ (RANGEL et al., 2000). According to Costa et al. (2003), the use of gliricidia as a protein supplement reduces the cost of animal feed, and its leaves provide a source of nonprotein nitrogen, peptides and amino acids that are important to the growth of microorganisms in the rumen. According to Carvalho Filho et al. (1997) and Costa et al. (2003), because of its palatability, gliricidia is not readily accepted the first few times it is offered, which is the result of an "in kind" natural reaction caused by the odor from the release of volatile phenolic compounds from the leaves, but dehydration resolves this problem. Costa et al. (2002) studied the effects of replacing concentrate with gliricidia hay offered ad libitum and did not observe an influence on the milk production in Alpine Brown and Saanen crossbreed goats when $50 \%$ of the concentrate was replaced. The higher cost of cattle raising is with feeding, especially when using supplemental sources such as corn, which generally have a high cost, making it necessary to use alternative food sources that do not compete directly with the other food. Therefore, the aim of this study was to evaluate the effects of partial replacement of corn by forage cactus along with gliricidia hay in the diets of lactating goats on the nutrient intake, milk production and composition, feeding behavior parameters and costs of production. 


\section{Material and Methods}

The experiment was conducted in situ in Grande Lagoon in the municipality of Nossa Senhora da Glória/SE. Five crossbred goats of the Saanen x Brown Alpine race, with body weights of $47 \pm 3.3 \mathrm{~kg}$, the second order of lactation and starting 60 days of lactation were used in the study. The animals were housed in individual pens measuring $3.0 \mathrm{~m}^{2}$ and were provided water and mineral salt ad libitum. The experiment was conducted from September to November 2011. The animals were distributed in a $5 \times 5$ Latin square: five animals, five treatments and five periods. Each experimental period lasted 17 days, 10 days for animal adaptation to the diets and seven days to collect data and samples (food, leftovers and milk). The treatments consisted of full rations of roughage and concentrate with partial substitution of corn (Zea mays L.) in 0.0, 18.0, 36.0, 54.0 and $72.0 \%$ by girl cactus (Nopalea cochenillifera Salm Dyck) at inclusion levels of 20, 25, 30, 35 and $40 \%$.

A complete ration was provided twice daily, $50 \%$ in the morning (08h00) and 50\% in the afternoon (15h30). Water was provided ad libitum, and the daily intake was quantified by the difference between that offered and the remainder during the trial period. The diets were formulated according to the National Research Council - NRC (1981) to meet the energy requirements $\left(\mathrm{DNT}=1.043 \mathrm{~g} \mathrm{day}^{-1}\right)$ and crude protein $\left(\mathrm{CP}=177 \mathrm{~g}\right.$ day $\left.^{-1}\right)$ of multiparous goats producing $1.5 \mathrm{~kg}$ milk day ${ }^{-1}$ and $3.5 \%$ fat. The chemical compositions of the experimental diets on the basis of dry matter are shown in Table 1, and the proportion of feed in the treatments is shown in Table 2.

Table 1. Chemical composition of the experimental diets (\%DM).

\begin{tabular}{lccccc}
\hline \multirow{2}{*}{ Items } & \multicolumn{5}{c}{ Corn replacement levels in the diets (\%) } \\
\cline { 2 - 5 } & $0 \%$ & $18 \%$ & $36 \%$ & $54 \%$ & $72 \%$ \\
\hline DM (\%) & 74.76 & 70.73 & 66.71 & 62.68 & 58.66 \\
DNT (\%) & 72.62 & 71.61 & 70.62 & 69.62 & 68.62 \\
CP (\%) & 11.76 & 11.43 & 11.10 & 10.77 & 10.44 \\
NDF (\%) & 36.08 & 36.47 & 36.85 & 37.24 & 37.62 \\
ADF ( $\left.\mathrm{g} \mathrm{kg}^{-1}\right)$ & 24.43 & 24.99 & 25.55 & 26.11 & 26.67 \\
\hline
\end{tabular}

Table 2. Composition of the diets.

\begin{tabular}{lccccc}
\hline \multirow{2}{*}{ Diets } & $0 \%$ & $18 \%$ & $36 \%$ & $54 \%$ & $72 \%$ \\
\cline { 2 - 5 } & & & Foods (\%) & \\
\hline Cracked corn & 28.0 & 23.0 & 18.0 & 13.0 & 8.0 \\
Gliricidia hay & 45.0 & 45.0 & 45.0 & 45.0 & 45.0 \\
Cactus & 20.0 & 25.0 & 30.0 & 35.0 & 40.0 \\
Molasses & 6.0 & 6.0 & 6.0 & 6.0 & 6.0 \\
Mineral salt & 1.0 & 1.0 & 1.0 & 1.0 & 1.0 \\
Total & 100.0 & 100.0 & 100.0 & 100.0 & 100.0 \\
\hline
\end{tabular}

Samples of the food provided to each animal, morning and afternoon, bagged, labelled and frozen. as well as the remainders, were collected in the The bromatological analyses were performed at the 
Animal Science Department of Animal Nutrition Laboratory of the Federal University of Sergipe (UFS). The determinations of dry matter (DM), mineral matter $(\mathrm{MM})$ and crude protein $(\mathrm{CP})$ were performed according to the methodology described by Silva and Queiroz (2002). For determination of the cell wall fractions of the neutral detergent fiber (NDF) and acid detergent fiber (ADF), the methods described by Van Soest et al. (1991) were followed. To determine the DNT, the regression equation $\mathrm{DNT}=91.0246$ to $0.571588 \times \mathrm{NDF}$, developed by Cappelle et al. (2001), was used. During the experimental period, two daily milkings $(07 \mathrm{~h} 00$ and $15 \mathrm{~h} 00$ ) were conducted, and milk samples were collected at these milkings on the 11th, 13th and 15 th days of each experimental period. The samples were collected in appropriate containers with a preservative tablet (Bronopol, Asacpharma Brasil, São Paulo, SP, Brasil) within each and were sent to the Animal Nutrition Laboratory of the Federal University of Sergipe, where the milk constituents were analyzed in a Lactoscan milk analyzer (LACTOSCAN). The feeding behavior was determined by the observation of individual animals for 24 uninterrupted hours in each trial period in 20 minute intervals, always beginning at the same time (CARVALHO et al., 2007). The observed and recorded behavioral variables were eating, ruminating, drinking, interacting (any activity other than those assessed other variables) and leisure. From these data, the average times spent eating, ruminating and idle were analyzed. The results of the feeding behavior were obtained through equations described by Polli et al. (1996): DWPE $=\mathrm{DMI} / \mathrm{TSE}\left(\mathrm{kg} \mathrm{DM} \mathrm{h}{ }^{-1}\right) ; \mathrm{DMRE}=\mathrm{DMI} / \mathrm{RUT}$ $\left(\mathrm{kg} \mathrm{DM} \mathrm{h}{ }^{-1}\right) ; \mathrm{TSE}=\mathrm{TCT}+\mathrm{RUT}\left(\mathrm{h} \mathrm{day}^{-1}\right)$, wherein: PE $\left(k g \mathrm{DM} \mathrm{h}^{-1}\right)=$ power efficiency; DMI (kg DM day $\left.^{-1}\right)=$ dry matter intake; TSE $\left(\mathrm{h} \mathrm{day}^{-1}\right)=$ feeding time; RE $\left(\mathrm{kg} \mathrm{DM} \mathrm{h}^{-1}\right)=$ rumination efficiency; RUT $\left(\mathrm{h} \mathrm{day}^{-1}\right)=$ rumination time; and TCT $\left(\right.$ time day $\left.{ }^{-1}\right)$ $=$ total chewing time. To determine the total cost of the $\mathrm{DM}$, prices $(\mathrm{R} \$)$ for the ingredients have been multiplied by the percentage used in the treatments given in Table 1. We considered values (in $\mathrm{kg}$, based on DM) approximate food in the State of Sergipe when the value of the dollar was R \$ 2.02: gliricidia hay $=\mathrm{R} \$ 0.20$; corn bran $=\mathrm{R} \$ 0.50$; cactus $=\mathrm{R} \$$ 0.20 ; mineral mixture $=\mathrm{R} \$ 1.25$ and $\mathrm{R} \$ 0.80=$ molasses. The milk receipts values $(\mathrm{R} \$)$ were obtained by multiplying the milk production $(\mathrm{kg}$ day $\left.^{-1}\right)$ of each treatment at the market price $(\mathrm{R} \$)$, the final price of the diet kilogram was calculated from the ratio of cost Total DM (R\$) and DM intake $\left(\mathrm{kg}\right.$ day $\left.^{-1}\right)$. The percentage of food with receipts commitment (FRC) was obtained from the ratio between total cost and DM milk received. Data were subjected to an analysis of variance and regression using the Analysis System Statistics and Genetics SAEG (UFV, 1998), and the effects of diets on the variables were measured at $5 \%$ probability using the Tukey test.

\section{Results and Discussion}

The inclusion levels of the cactus in the diets did not influence $(\mathrm{P}>0.05)$ the dry matter intake (DMI), crude protein (CP), neutral detergent fiber (NDF), acid detergent fiber (ADF) and digestible nutrients total (DNT), with average consumption of $1.64,0.26,0.82,0.54$ and $1.17 \mathrm{~kg} \mathrm{day}^{-1}$, respectively (Table 3).

According to the NRC (1981), the recommended average consumption of DM for a goat with an average body weight of $50 \mathrm{~kg}$ and producing 1.5 $\mathrm{kg}$ milk day ${ }^{-1}$ with $3.5 \%$ fat content is $1.61 \mathrm{~kg} \mathrm{DM}$ day $^{-1}$ and $4-5 \%$ LW, values that approximate the mean values obtained in the present study (1.64 $\mathrm{kg} \mathrm{DM} \mathrm{day}{ }^{-1}$ and $4.12 \% \mathrm{LW}$ ), which fully met the requirements for the daily DM intake by the animals. The average daily consumption of $\mathrm{PB}$ was not influenced by the partial substitution of corn, possibly because of the many values in the diets that approached the crude protein content requirements and the lack of change in DM. The average consumption of CP was found to be 0.260 $\mathrm{kg}$ day $^{-1}$, a value exceeding the $0.177 \mathrm{~kg} \mathrm{CP}$ day $^{-1}$ 
recommended by the NRC (1981). With rising cactus levels in the diets, there was no significant increase in the NDF and ADF values in the composition not influencing the consumption of these nutrients for animals, possibly by stable participation gliricidia hay as fiber source. The diets showed variations from 36.08 to $37.62 \%$ and from 24.43 to $26.67 \%$ for NDF and ADF, respectively. Consumption of the DNT was not influenced $(\mathrm{P}>0.05)$ by the inclusion of the cactus, with a mean of $1.17 \mathrm{~kg}^{\mathrm{DNT}}$ day $^{-1}$ being consumed. Despite the partial withdrawal of the power source, such as the corn, the cactus and molasses met the minimum requirements of the energy consumption recommended by the NRC (1981) which is 1.04 kg DNT day ${ }^{-1}$. Possibly, the inclusion of cactus may increase the amount of nonfiber carbohydrate (NFC), nutrients that rapidly degrade in the rumen, favoring microbial activity and hence fiber digestion (WANDERLEY et al., 2002), thus meeting the minimum energy requirements of the animals. Water consumption was reduced linearly $(\mathrm{P}<0.05)$ with the increase in the amount of forage cactus consumed. The mean values ranged from 1.34 to $0.48 \mathrm{~kg}$ water day ${ }^{-1}$. The cactus has contributed significantly in providing water for animals, thereby reducing the need for consumption, thus underscoring the importance of forage as a source of water for the animals promoting economy of $64.45 \%$ of the value ( $R \$$ ) to be paid to the water consumed compared the diets with 20 and $40 \%$ share this cactaceous. These results corroborate those obtained by Costa et al. (2009), who evaluated the effects of increasing the levels of forage cactus (Opuntia ficus-indica L. Miller) in diets of lactating goats and its contribution as a source of water they observed a linear reduction ( $\mathrm{P}$ $<0.01)$ in water intake $\left(5.34-0.12 \mathrm{~kg} \mathrm{day}^{-1}\right)$ with the increase of cactus content in the diet $(0-28 \%)$. No effect $(\mathrm{P}>0.05)$ was observed on the diets in daily milk production and fat, protein, lactose and total milk solids, with the means equal to $1.18 \mathrm{~kg}^{-}$day $^{-}$ 1 , 3.74, 3.34, 5.06 and $13.56 \%$, respectively. This lack of variation in milk yield and composition may have been influenced by the constant consumption of the DM, CP, NDF, ADF and DNT observed in this study (Table 4).

Table 3. Average values of nutrient intake, regression equations (RE), coefficients of variation (CV) and the coefficient of determination $\left(\mathrm{R}^{2}\right)$.

\begin{tabular}{|c|c|c|c|c|c|c|c|c|c|}
\hline \multirow{2}{*}{ Item } & \multicolumn{5}{|c|}{ Corn replacement levels (\%) } & \multirow{2}{*}{ RE } & \multirow{2}{*}{$\mathrm{CV}(\%)$} & \multicolumn{2}{|c|}{$\mathrm{R}^{2}$} \\
\hline & $0 \%$ & $18 \%$ & $36 \%$ & $45 \%$ & $72 \%$ & & & $\mathrm{~L}$ & Q \\
\hline $\mathrm{DM} / \mathrm{kg} /$ day & 1.51 & 1.62 & 1.76 & 1.72 & 1.58 & $\hat{\mathrm{Y}}=1.64$ & 18.10 & NS & NS \\
\hline $\mathrm{DM} / \% \mathrm{LW}$ & 3.85 & 4.14 & 4.21 & 4.37 & 4.01 & $\hat{\mathrm{Y}}=4.12$ & 19.29 & NS & NS \\
\hline $\mathrm{DM} / \mathrm{g} / \mathrm{kg}^{0,75}$ & 84.29 & 90.09 & 98.03 & 95.68 & 88.11 & $\hat{\mathrm{Y}}=91.24$ & 20.85 & NS & NS \\
\hline $\mathrm{CP} / \mathrm{kg} /$ day & 0.23 & 0.25 & 0.28 & 0.27 & 0.27 & $\hat{\mathrm{Y}}=0.26$ & 20.12 & NS & NS \\
\hline $\mathrm{CP} / \mathrm{g} / \mathrm{kg}^{0,75}$ & 12.25 & 13.46 & 14.74 & 14.59 & 14.22 & $\hat{\mathrm{Y}}=13.85$ & 20.33 & NS & NS \\
\hline $\mathrm{NDF} / \mathrm{kg} /$ day & 0.68 & 0.77 & 0.87 & 0.89 & 0.90 & $\hat{\mathrm{Y}}=0.82$ & 20.34 & NS & $\mathrm{NS}$ \\
\hline $\mathrm{NDF} / \mathrm{g} / \mathrm{kg}^{0,75}$ & 36.23 & 41.03 & 46.38 & 47.49 & 47.97 & $\hat{\mathrm{Y}}=43.82$ & 20.03 & NS & NS \\
\hline $\mathrm{ADF} / \mathrm{kg} /$ day & 0.44 & 0.50 & 0.57 & 0.59 & 0.60 & $\hat{\mathrm{Y}}=0.54$ & 19.59 & NS & NS \\
\hline $\mathrm{ADF} / \mathrm{g} / \mathrm{kg}^{0,75}$ & 23.57 & 26.79 & 30.39 & 31.25 & 31.69 & $\hat{\mathrm{Y}}=28.74$ & 20.04 & NS & NS \\
\hline DNT/kg/day & 1.09 & 1.17 & 1.26 & 1.21 & 1.10 & $\hat{\mathrm{Y}}=1.17$ & 21.86 & NS & NS \\
\hline $\mathrm{DNT} / \mathrm{g} / \mathrm{kg}^{0,75}$ & 58.21 & 62.01 & 67.02 & 64.69 & 58.74 & $\hat{\mathrm{Y}}=62.13$ & 21.86 & NS & NS \\
\hline
\end{tabular}

$\mathrm{NS}=$ non-significant at $5 \%$ probability by the Tukey test.

$1^{*} \mathrm{y}=1,610-0,236 \mathrm{SC}$, when $\mathrm{SC}=$ level of spineless cactus

$* * \mathrm{P}<0.05$. 
The important thing to note in these results is the potential for cactus to be used as a partial replacement of corn for goats in the production of milk without changing the milk production and composition. The average percentage of fat found in the milk was $3.74 \%$, remaining close to the average (3.7\%) observed for crossbred goats Saanen $\mathrm{x}$ Alpine in work done by Pizarro and Bresslau (2001). An important fact to consider is that the fat, protein, lactose and total solids found meet the minimum required by Brazilian law for goat milk quality (2.9, 2.8, 4.3 and 8.2\%, respectively) (BRASIL, 2000). The results of the time spent eating (TSE h day ${ }^{-1}$ ), in rumination (RUT, h day ${ }^{-1}$ ), leisure time (LT h day ${ }^{1}$ ); the total chewing time (TCT, h day $\left.{ }^{-1}\right)$; the DM power efficiency $\left(\mathrm{DMPE}, \mathrm{kg} \mathrm{DM} \mathrm{h} \mathrm{h}^{-1}\right)$; and the DM rumination efficiency (DMRE, $\mathrm{kg} \mathrm{DM} \mathrm{h} \mathrm{h}^{-1}$ ) of the goat feeding behavior are shown in Table 5 .

Table 4. Mean values, regression equations (RE), coefficients of variation (CV) and the coefficient of determination $\left(\mathrm{R}^{2}\right)$ for the production of milk and its physiochemical composition.

\begin{tabular}{|c|c|c|c|c|c|c|c|c|c|}
\hline \multirow{2}{*}{ Item } & \multicolumn{5}{|c|}{ Replacement levels (\%) } & \multirow{2}{*}{$\mathrm{RE}$} & \multirow{2}{*}{$\mathrm{CV}(\%)$} & \multicolumn{2}{|c|}{$\mathrm{R}^{2}$} \\
\hline & $0 \%$ & $18 \%$ & $36 \%$ & $45 \%$ & $72 \%$ & & & $\mathrm{~L}$ & $\mathrm{Q}$ \\
\hline MP (kg/day) & 1.13 & 1.14 & 1.23 & 1.32 & 1.12 & $\hat{\mathrm{Y}}=1.18$ & 12.60 & NS & $\mathrm{NS}$ \\
\hline Fat $(\%)$ & 3.32 & 3.67 & 3.09 & 3.99 & 3.64 & $\hat{\mathrm{Y}}=3.74$ & 15.43 & NS & NS \\
\hline Protein $(\%)$ & 3.25 & 3.18 & 3.72 & 3.22 & 3.36 & $\hat{\mathrm{Y}}=3.34$ & 9.70 & NS & NS \\
\hline Lactose (\%) & 4.91 & 4.95 & 5.56 & 4.80 & 5.06 & $\hat{Y}=5.06$ & 10.10 & NS & NS \\
\hline TS (\%) & 13.48 & 13.44 & 13.69 & 13.39 & 13.80 & $\hat{Y}=13.56$ & 9.58 & NS & NS \\
\hline
\end{tabular}

$\mathrm{NS}=$ non-significant at $5 \%$ probability by the Tukey test.

$\mathrm{MP}=$ milk production; $\mathrm{MPC}=$ milk production corrected $3.5 \%$ fat; $\mathrm{TS}=$ total solids

Table 5. Mean values, regression equations (RE), coefficients of variation (CV) and the coefficient of determination $\left(\mathrm{R}^{2}\right)$ of the time spent eating (TSE, $h$ day $\left.^{-1}\right)$, ruminating $\left(\mathrm{RUT}, \mathrm{h}\right.$ day $\left.{ }^{-1}\right)$, and at leisure time (TL, $\mathrm{h}$ day $\left.{ }^{-1}\right)$; total chewing time (TCT, $h$ day $^{-1}$ ); DM power efficiency (DMPE, $\mathrm{kg} \mathrm{DM} \mathrm{h}^{-1}$ ); and DM rumination efficiency (DMRE, $\mathrm{kg} \mathrm{DM} \mathrm{h}^{-1}$ ) with the levels of cactus in the experimental diets.

\begin{tabular}{|c|c|c|c|c|c|c|c|c|c|}
\hline \multirow{2}{*}{ Item } & \multicolumn{5}{|c|}{ Cactus levels in the diets $(\%)$} & \multirow{2}{*}{$\mathrm{RE}$} & \multirow{2}{*}{$\mathrm{CV}(\%)$} & \multicolumn{2}{|c|}{$\mathrm{R}^{2}$} \\
\hline & 20 & 25 & 30 & 35 & 40 & & & $\mathrm{~L}$ & Q \\
\hline TSE & 4.54 & 4.86 & 4.58 & 4.20 & 4.14 & $\hat{\mathrm{Y}}=4.46$ & 23.79 & NS & NS \\
\hline RUT & 4.18 & 5.34 & 5.90 & 6.20 & 6.12 & $\hat{Y}=5.54$ & 22.35 & NS & NS \\
\hline LT & 14.07 & 12.53 & 11.97 & 12.76 & 12.62 & $\hat{Y}=12.79$ & 12.12 & NS & NS \\
\hline TCT & $8 ., 72$ & 10.20 & 10.48 & 10.40 & 10.26 & $\hat{\mathrm{Y}}=10.01$ & 16.41 & NS & NS \\
\hline $\mathrm{PE}_{\mathrm{DM}}$ & 0.36 & 0.41 & 0.47 & 0.50 & 0.39 & $\hat{\mathrm{Y}}=0.43$ & 53.79 & NS & NS \\
\hline $\mathrm{RE}_{\mathrm{DM}}$ & 0.43 & 0.37 & 0.30 & 0.27 & 0.27 & $\hat{\mathrm{Y}}=0.33$ & 37.90 & NS & NS \\
\hline
\end{tabular}

$\mathrm{NS}=$ non-significant at $5 \%$ probability by the Tukey test.

$1^{*} \mathrm{Y}=-0,072 \mathrm{x}^{2}+0,524 \mathrm{x}+0,358\left(\mathrm{r}^{2}=0,827\right)$.

No effects $(\mathrm{P}>0.05)$ were observed from the various forage cactus levels in the experimental diets for the feeding behavior parameters evaluated. Possibly, this lack of influence may be related to the low amplitude variation between the NDF levels of the experimental diets (1.54\%). According to Van Soest (1994), the time spent in feeding and rumination is proportional to the cell wall content of the foods; therefore, an increase in the level of NDF in the diets will increase the time spent eating and 
ruminating. However, in this study little variation existed in the NDF among the experimental diets, so no influence was observed on the TSE, RUT and LT. The total chewing time, with an average value of $10.01 \mathrm{~h} \mathrm{day}^{-1}$, was not influenced $(\mathrm{P}>0.05)$ by the amount of cactus. Possibly, no significant difference occurred because of the similarity between the time spent eating and ruminating the diets and because this variable is obtained by adding the time spent in these two activities. The results of the feeding and rumination efficiencies were not affected by the different levels of cactus provided in the treatment diets, with average values of 0.43 and $0.33 \mathrm{~kg}$ $\mathrm{DM} \mathrm{h}^{-1}$, respectively. This result can be explained also by the similar consumption of DM observed in this study. Table 6 shows an evaluation of the food with the composition adjustments (FRC). The FRC with the $25 \%$ cactus treatment was higher (37.36\%) compared to other levels of inclusion, and the treatment with $35 \%$ cactus showed the lowest commitment (31\%), amounting to savings of $6.6 \%$ for the diet with the $35 \%$ inclusion of cactus. Another important thing to note is that, although the final price per kilogram of diet showed a decrease of $18.18 \%$ when the diets with 20 and $40 \%$ cactus inclusion were compared, the diet with $35 \%$ cactus inclusion showed a lower value of FRC. The positive results of this study with regard to the reduction in production costs, plus the nutritional aspects of the cactus, underscore the importance of this forage in the composition of diets for dairy goats in the semiarid region.

Table 6. Milk production, dry matter intake (DM), cost of dry matter $(\mathrm{kg})$ price of milk, revenue, costs and food with receipts commitment (FRC).

\begin{tabular}{lccccc}
\hline & \multicolumn{7}{l}{ Inclusion levels of forage cactus in the diet (\%) } & & \\
\cline { 2 - 6 } & $20 \%$ & $25 \%$ & $30 \%$ & $35 \%$ & $40 \%$ \\
\hline Milk production (kg/day) & 1.13 & 1.14 & 1.23 & 1.32 & 1.12 \\
DM intake (kg/day) & 1.51 & 1.62 & 1.76 & 1.72 & 1.58 \\
Total cost DM(R\$) & 0.50 & 0.51 & 0.53 & 0.49 & 0.43 \\
Milk price (R\$) & 1.20 & 1.20 & 1.20 & 1.20 & 1.20 \\
Milk receipts (R\$) & 1.36 & 1.37 & 1.48 & 1.58 & 1.34 \\
Diet (R\$)/kg DM & 0.33 & 0.32 & 0.30 & 0.29 & 0.27 \\
FRC (\%) & 36.80 & 37.36 & 35.83 & 31.00 & 31.80 \\
\hline
\end{tabular}

\section{Conclusions}

The partial replacement of corn by girl cactus in the diets for dairy goats can be accomplished because this replacement did not alter the intake, milk yield or composition and feeding behavior of the goats. Replacement of as much as $54 \%$ of the corn by cactus is recommended to reduce production expenditures on feed.

\section{References}

BELTRÃO FILHO, E. M. Produção, composição química e sensorial do leite de cabras alimentadas com palma forrageira (Opuntia ficus-indica L. Miller) em substituição ao milho. 2008. Tese (Doutorado Integrado em Zootecnia) - Universidade Federal da Paraíba, Areia.

BRASIL. Ministério da Agricultura. Secretaria Nacional da Agricultura. Instrução Normativa $\mathrm{n}^{\circ} 37$, de 8 de novembro de 2000. Regulamento Técnico de 
Produção, identidade e qualidade do leite de cabra. Diário Oficial [da] União. Brasília, 8 nov. 2000. Seção 1, p. 23. Disponível em: <http://www.agricultura.gov.br/ legislacao/sislegis $>$. Acesso em: 14 jan. 2015.

CAPPELLE, E. R.; VALADARES FILHO, S. C.; SILVA, J. F. C.; CECON, P. R. Estimativas do valor energético a partir de características químicas e bromatológicas dos alimentos. Revista Brasileira de Zootecnia, Viçosa, MG, v. 30, n. 6, p. 1837-1856, 2001.

CARVALHO FILHO, O. M. de; DRUMOND, M. A.; LANGUIDEY, P. H. Gliricídia sepium: leguminosa promissora para regiões semi-áridas. Petrolina: EMBRAPA- CPATSA, 1997. 16 p. (EMBRAPACPATSA. Circular técnica, 35).

CARVALHO, G. G. P. de; PIRES, A. J. V.; SILVA, H. G. de O.; VElOSO, C. M.; SILVA, R. R. Aspectos metodológicos do comportamento ingestivo de cabras lactantes alimentadas com farelo de cacau e torta de dendê. Revista Brasileira de Zootecnia, Viçosa, MG, v. 36, n. 1, p. 103-110, 2007.

COSTA, B. M. da; SANTOS, I. C. V.; OLIVEIRA, G. J. C. de; PEREIRA, I. G. Avaliação de folhas de Gliricídia sepium (JACQ.) por ovinos. Archivos de Zootecnia, Córdoba, v. 58, n. 221, p. 33-41, 2003.

COSTA, R. G.; BELTRÃO FILHO, E. M.; MEDEIROS, A. N.; GIVISIEZ, P. E. N.; QUEIROGA, R. C. R. E. MELO, A. A. S. Effects of increasing levels of cactus pear (Opuntia ficus-indica L. Miller) in the diet of dairy goats and its contribution as a source of water. Small Ruminant Research, Amsterdam, v. 82, n. 2, p. 62-65, 2009.

COSTA, R. G.; MARTINS, T. D. D.; ARAÚJO, J. A.; WANDERLEY, A. S.; SILVA, J. H. V.; CRUZ, G. B.; VÁSQUEZ, S. F. Utilización de Gliricídia (Gliricídia sepium) y Leucena (Leucaena leucocephala) en la alimentación de cabras en lactación. In: XXVII JORNADAS CIENTÍFICAS Y VI JORNADAS INTERNACIONALES DE LA SOCIEDAD ESPAÑOLA DE OVINOTECNIA Y CAPRINOTECNIA, 27; 6 , 2002, Valencia. Anales... Valencia: CEU, 2002. p. 154159.

DE KOCK, G. C. The use of Opuntia as a fodder source in arid areas of South Africa. In: MONDRAGON, C.; GONZALEZ, S. (Ed.). Cactus (Opuntia spp.) as forage. México: FAO Plant Production and Protection Paper, 2001. v. 169, p. 73-90.

DUSKOVÁ, D.; MAROUNEK, M. Fermentation of pectin and glucose, and activity of pectin-degrading enzymes in the rumen bacterium Lachnospira multiparus. Letters in Applied Microbiology, Oxford, v. 33, n. 2, p. 159-163, 2001.
MELO, A. A. S.; FERREIRA, M. A.; VERÁS, A. S. C.; LIRA, M. A.; LIMA; L. E.; VILELA, M. S.; MELO, E. O. S.; ARAÚJO, P. R. B. Substituição parcial do farelo de soja por ureia e palma forrageira (Opuntia ficus indica Mill.) em dietas para vacas em lactação. I. Desempenho. Revista Brasileira de Zootecnia, Viçosa, MG, v. 32, n. 5, p. 727-736, 2003.

NATIONAL RESEARCH COUNCIL - NRC. Nutrient requirements of goats. National Academy Press. Washington, D.C. 1981.91 p.

PIZARRO, C.; BRESSLAU, S. Custo de produção do leite de cabra. In: ENCONTRO DE CAPRINOCULTORES DO SUL DE MINAS E MEDIA MOGIANA-CREUPI, 2001, Espírito Santo do Pinhal. Anais... Espírito Santo do Pinhal: CREUPI, 2001. p. 1-21.

POLLI, V. A.; RESTLE, J.; SENNA, D. B.; ALMEIDA, S. R. S. Aspectos relativos à ruminação de bovinos $\mathrm{e}$ bubalinos em regime de confinamento. Revista Brasileira de Zootecnia, Viçosa, MG, v. 25, n. 5, p. 987-993, 1996.

RANGEL, J. H. de A.; CARVALHO FILHO, O. M.; ALMEIDA, S. A. Experiências com uso de Gliricídia sepium na alimentação animal no nordeste brasileiro. In: CONGRESSO BRASILEIRO DE FRUTICULTURA, 16, 2000, Fortaleza. Anais... Fortaleza: EMBRAPAAgroindústria Tropical/SBF, 2000. CD-ROM.

SILVA, D. J.; QUEIROZ, A. C. Análise de alimentos: métodos químicos e biológicos. 3. ed. Viçosa, MG: UFV, 2002. $253 \mathrm{p}$.

UNIVERSIDADE FEDERAL DE VIÇOSA - UFV. SAEG - Sistema de análises estatísticas e genéticas. Viçosa, MG: UFV, 1998. CD-ROM.

VAN SOEST, P. J. Nutritional ecology of the ruminant. $2^{\text {th }}$ ed. Ithaca: Cornell University Press, 1994. 476 p.

VAN SOEST, P. J.; ROBERTSON, J. B.; LEWIS, B. A. Methods for dietary fiber, neutral detergent fiber and nonstarch polysaccharides in relation to animal nutrition. Symposium: carbohydrate methodology, metabolism and nutritional implications in dairy cattle. Journal of Dairy Science, Madison, v. 74, n. 10, p. 3583-3597, 1991.

WANDERLEY, W. L.; FERREIRA, M. A.; ANDRADE, D. K. B.; VERAS, A. S. C.; FARIAS, I.; LIMA, L. E.; DIAS, A. M. A. Palma forrageira (Opuntia ficus indica Mill) em substituição a silagem de sorgo (Sorghum bicolor (L.) Moench) na alimentação de vacas leiteiras. Revista Brasileira de Zootecnia, Viçosa, MG, v. 31, n. 1, p. 273-281, 2002. 